\title{
Vestjysk stød, Icelandic preaspiration, and Proto-Indo-European glottalic stops
}

\author{
Frederik Kortlandt
}

1. In his monograph on the vestjysk stød, K. Ringgaard concludes 'that the $\mathrm{v}$-stød is only found immediately before the plosives $p, t, k$, and that it is found wherever these stand in an original medial position, following a voiced sound in a stressed syllable. The exceptions to this are certain types of loan-words from a later period' (Ringgaard 1960: $10,195)$. 'The v-stød is a complete occlusion of the vocal chords, combined with the diaphragm's movement of inhalation, equalizing the difference in pressure, and caused by an attempt to pronounce pure and unaspirated fortes plosives when medial' (Ringgaard 1960: 199), i. e., a full-fledged glottal stop. Ringgaard dates the rise of the vestjysk stød to the 12 th century because it is characteristic of 'all then existing medial plosives'. The view that the vestjysk stød originated from a phonetic development of fortes plosives in medial position was already put forward by A. Pedersen (1912: 42), who compared the development with the rise of preaspiration in Icelandic. It is an elaboration of A. Kock's hypothesis that the vestjysk stød represents 'en ljudaffektion, som inträtt vid tenues i vissa ställningar' (Kock 1891: $368 \mathrm{fn}$, similarly 1901: $26 \mathrm{fn}$ ).

Accepting the thesis that the rise of the vestjysk stød has nothing to do with accentuation or apocope, we are faced with three conflicting theories on its origin:

Tl: ${ }^{t}<h t$ (A. Pedersen 1912: 42). This view is accepted by H. Pedersen (1942: 119).

T2: ?t $<t$ (Jespersen 1913: 23). This view is accepted by Ringgaard (1960: 108).

T3: $t<t t$ (Skautrup 1928: 45). This view is explicitly rejected by Hansen (1943: 135).

The difference between these three proposals must not be exaggerated. All of them start from the conviction that the origin of the glottal stop must be sought in a series of fortes plosives. The disagreement concerns the phonetic probability of the proposed developments. Ringgaard unjustly repeats Jespersen's objection to Pedersen's view: both 
the rise of glottalization from preaspiration and the rise of preaspiration from a preceding glottal stop are well attested, e. g., in Burmish languages (cf. Bradley 1979: 127-131). Ringgaard's own view that the vestjysk stød is a spontaneous innovation of the western dialects can hardly be called an explanation. Moreover, it does not account for the parallel development of preaspiration in Icelandic.

2. Preaspiration is found not only in Icelandic, but also in Faroese, West Norwegian, and the Gaelic dialects of Scotland. Phonetically, the preceding vowel is cut short and continued as a whisper; a preceding resonant $(m, n, l, r)$ is partly or wholly unvoiced. The distribution of preaspiration in Icelandic has been clarified in E. Haugen's lucid analysis of the phonemic system (1941, cf. also 1958). It turns out that $/ b, d, g /$ differ from $/ p, t, k /$ in the absence of preaspiration, except in initial position, where they are distinctively unaspirated. The opposition is neutralized after fricatives and after long vowels, where preaspiration is lost. All obstruents are usually voiceless. The same distribution is found in the Norwegian dialect of Jæren (Oftedal 1947). Preaspiration is also attested in Hallingdal, northern Gudbrandsdal, Trøndelag, and even Herjedal. We can conclude that it must have been common to a much larger area and that it is "an example of a feature taken to Iceland by the original settlers" (Chapman 1962: 85).

C. Marstrander has argued that the preaspiration in Scottish Gaelic is due to a Norse substratum (1932: 298). He advances the hypothesis that the Norwegian preaspirated stops represent a retention of the clusters $h p, h t, h k$, which developed into geminates elsewhere (302). He adduces ME haht, saht, slahter < ON hátta 'danger', sátt, sátt 'agreement', sláttr 'mowing' as evidence for the view that the cluster $h t$ had not yet merged with the geminate $t t$ in the 10th century. His theory implies three developments:

D1: $t t<h t$ in East Norse;

D2: $h t<t t$ in West Norse;

D3: $h t<t$ in West Norse in those positions where the preaspirated stop does not reflect a cluster, e.g., Icelandic epli 'apple', vopn 'weapon', opna 'open', gutl 'dabbling', vatn 'water', batna 'improve', mikla 'increase', pukla 'touch', teikn 'token', likna 'show mercy', hjálpa 'help', verpa 'throw', elta 'pursue', erta 'tease', folk 'people', verk 'work'. Here the preaspirated stop appears to be the phonetic reflex of a Proto-Indo-European unaspirated voiced plosive. 
3. Elsewhere I have argued that the reconstructed voiced plosives of the Indo-European proto-language were actually glottalic and that the glottalization has been preserved in Balto-Slavic, Armenian, and Indo-Iranian, and has left traces in Greek and Latin (1978, 1983). Both the vestjysk stød and the Icelandic preaspiration receive a natural explanation if we assume that Early Proto-Germanic, like Proto-Balto-Slavic and Proto-Indo-Iranian, possessed a series of preglottalized voiced stops. Devoicing yielded a series of Late ProtoGermanic sequences $? p, ? t, k$. Syllable-final glottal stop was lost. Subsequently, weakening of the glottal stop in West Norse yielded preaspiration, while its assimilation to the following plosive gave rise to a series of geminates in East Norse, with the exception of Danish, where the plosives were subject to lenition and the glottal stop was preserved in the westernmost dialects. I wonder if Swedish vecka 'week', droppe 'drop', skepp 'ship' reflect a dialect that escaped the earliest loss of the glottal stop.

One may wonder if preglottalization had been preserved in wordinitial position in Late Proto-Germanic. There is positive evidence for this idea in the vestjysk stød of fattig < fát'økr 'poor' < 'fewtaking' and sytten 'seventeen'.

Apart from the straightforward explanation of the vestjysk stød and the Icelandic preaspiration, the theory advanced here has the advantage of accounting in a principled way for the existence of several layers of gemination, which can now be viewed as retentions rather than innovations:

G1: $m p, n t, n k$ yielded $p p, t t, k k$ in the larger part of Scandinavia. The nasal consonant was apparently unvoiced by the laryngeal feature which preceded the plosive, and subsequently lost its nasalization.

G2: $k$ yielded $k k$ before $j$ and $w$. Similarly, $t$ yielded $t t$ before $j$ in a limited area, e. g., Swedish sätta 'set'. The development cannot easily be identified with the change of $g$ into $g g$ before $j$ because the latter involves the transformation of a fricative into a plosive. Modern Icelandic / b , d, g/ are lengthened after a short vowel before $n$ and $l$, e.g., rigna 'rain', sigla 'sail', with half-long $g$. West Germanic geminated all consonants except $r$ before $j$.

G3: $p, t, k$ yielded $p p, t t, k k$ before $r$ and $l$ in West Germanic. The same development is found sporadically in Scandinavia. Here again, the geminate may have originated from the assimilation of a glottal stop to the following plosive. 
4. It is possible that the theory put forward here has certain consequences for the interpretation of the West Germanic material. Firstly, the High German sound shift may have resulted from a lenition of the plosives with concomitant oralization of the preceding glottal stop. If this is correct, the glottalization must have been preserved at the time of the shift. Secondly, the absence of aspirated stops from Dutch and Frisian may be due to an early loss of preglottalization in this area. Thirdly, the English glo?al sto? may be much more ancient than is commonly assumed. It appears that these possibilities merit further consideration.

The evidence for the preservation of the Proto-Indo-European glottalic obstruents in Proto-Germanic supports the hypothesis that there also was a glottal stop of laryngeal origin. Oralization of the latter yielded $k$ before $w$ in the following instances (cf. Austin 1946, 1958; Lehmann 1965: 216):

- OE haccian 'hack' < *kaHw- next to heawan 'hew' with laryngeal metathesis.

- OE leccan 'moisten' < *laHw-.

- OE naca 'boat' <*naHw-.

- OE cwic 'alive' $<{ }^{*} g^{w} i H w-<{ }^{*} g^{w} H i w-$.

- ON skeika 'swerve' <*skaiHw- <*skaHiw-.

- OHG speichaltra 'spit' <* speiHw- <*speHiw- next to spiwan with further laryngeal metathesis.

- OE spic 'fat' $<{ }^{*}$ spiHw- $<{ }^{*}$ spHiw-.

- OE staca 'haystack' < ${ }^{*}$ staHw-.

- OE tācor 'brother-in-law' $<*$ daiHw- $<*$ daHiw-.

There is no evidence for a similar development before $j$, where a laryngeal lengthened the preceding vowel, e. g., OHG tāju 'suck'. The rise of $-u g$ - from antevocalic ${ }^{*}-u H$ - must be explained as a secondary development (cf. Winter 1965: 198). The intervocalic sequences ${ }^{*}-w H-$ and $*_{-j} j$ - yielded $*_{-} w w$ - and $*_{-j j}$ - in Proto-Germanic.

\section{References}

Austin, William M.

1946

"A corollary to the Germanic Verschärfung", Language 22: $109-$ 111.

1958 "Germanic reflexes of Indo-European - Hy- and -Hw-", Language 34: 203-211. 
Bradley, David

1979

Proto-Lolotsh (Copenhagen Scandinavian Institute of Asıan Stud1es)

Chapman, Kenneth $\mathrm{G}$

1962

Icelandic-Norwegian linguıstıc relatıonships (Oslo Unıversitetsforlaget)

Hansen, Aage

1943 Stødet t Dansk (København Munksgaard)

Haugen, Einar

1941

"On the consonant pattern of modern Icelandic", Acta Linguistica $298-107$

1958 "The phonemics of modern Icelandic", Language 34 55-88

Jespersen, Otto

"Det danske stød og urnordisk synkope", Arktv for Nordisk Filologt $29 \quad 1-32$

Kock, Axel

1891

"Fornnordiska kvantitets- och akcentfrågor", Arkıv for Nordisk Filo$\log \imath 7334-377$

1901 Die alt-und neuschwedische Accentuterung (Strassburg Trubner)

Kortlandt, Frederik

1978 "Proto-Indo-European obstruents", Indogermanische Forschungen $83 \quad 107-118$

1983 "Greek numerals and PIE glottalıc consonants", Munchener Studien zur Sprachwissenschaft 42 97-104

Lehmann, Winfred $\mathbf{P}$

1965 "Germanic evidence", in Werner Winter (ed ), Evidence for laryngeals (The Hague Mouton), 212-223

Marstrander, Carl J S

1932 "Okklusiver og substrater", Norsk Tidsskrıft for Sprogvidenskap 5 $258-314$

Oftedal, Magne

1947 "Jærske okklusıvar", Norsk Tidsskrift for Sprogvidenskap $14229-$ 235

Pedersen, Anders

1912 "Dansk og urnordisk akcentuerıng", Arkıv for Nordısk Fılologı 28 $1-53$

Pedersen, Holger

1942 "Er stødet en konsonant?", Acta Phllologica Scandinavica 16111 120

Runggaard, Kristian

1960 Vestjysk stød (Aarhus Universitetsforlaget)

Skautrup, Peter

1928 “Klusiler og 'yngre’ stød 1 vestjysk”, Acta Philologıca Scandinavica $332-51$

Winter, Werner

1965

"Tocharian evidence", in Werner Winter (ed ), Evidence for laryngeals (The Hague Mouton), 190-211 